\title{
Efek Kedelai Terhadap Faal Ginjal Diabetes Melitus
}

\author{
Putri Dafriani $^{\mathrm{a}}$ \\ ${ }^{\text {a }}$ Stikes Syedza Saintika Padang \\ Email : putridafrianiabd@gmail.com
}

\begin{abstract}
Diabetes mellitus is a metabolism disease associated with a number of microvascular (retinopathy, neuropathy and nephropathy) and macrovascular (ischaemic heart disease, cerebrovascular disease and peripheral vascular diseases) complications. Soybeans have been consumed for a long time as an important protein source to complement grain protein soybean contain various nutritious and functional components such as isoflavonoids, which are beneficial against stress oxidative. This study aimed to explain soybean effect to nephropathy diabetic. Soybean have some advantages like isoflavonoids, protein, fiber, and fitoestrogen. All of advantages are used to eliminate diabetic complication.
\end{abstract}

Keywords: Diabetes, nephropathy diabetic, soybean

\begin{abstract}
Abstrak : Diabetes Melitus (DM) merupakan kelainan metabolik yang dihubungkan dengan sejumlah kelainan mikrovaskular (retinopati, neuropati dan nefropati ) dan makrovaskular (serebrovaskular, kelainan pembuluh darah perifer dan penyakit jantung). Kedelai merupakan salah satu makanan fungsional yang memiliki banyak manfaat terutama dalam penanganan diabetes mellitus. Tujuan tinjauan pustaka ini adalah untuk membahas peranan kedelai dalam menangani komplikasi diabetes terutama terhadap nefropati diabetes. Kedelai merupakan salah satu alternatif dalam mengurangi komplikasi atau dampak lanjut dari DM. Kedelai mengandung antioksidan yang dapat menetralisir radikal bebas akibat hiperglikemi.
\end{abstract}

Kata Kunci : Diabetes, Nefropati Diabetik, kedelai

Diabetes Mellitus (DM) adalah kelainan metabolik kronik(Rebsomen, 2008) ditandai dengan poliuria, polidipsia, polifagia, hiperglikemia, glikosuria, ketosis, asidosis dan koma. Kelainan metabolik pada diabetes dihubungkan dengan perubahan patofisiologi pada banyak sistem organ. Hiperglikemia umumnya disebabkan oleh malfungsi sekresi insulin dan atau kerja insulin yang tidak memadai(Auroma, 2006).

Saat ini diabetes berada di peringkat empat dari lima penyebab kematian di negara maju. Kecenderungan ini melebar ke negara berkembang dan negara industri baru. Kematian bukan terjadi akibat diabetes secara langsung, melainkan dari komplikasi yang terjadi. Kadar gula darah tinggi terusmenerus akan merusak jaringan tubuh dan menimbulkan pelbagai komplikasi seperti penyakit jantung, neuropati diabetik, nefropati diabetik, dan retinopati diabetik. Hal ini meningkatkan kasus kecacatan, menurunkan usia harapan hidup, dan meningkatkan biaya pemeliharaan kesehatan (Obrien, 2003).

Angiopati pada diabetes menjadi penyebab utama angka kesakitan dan kematian pada diabetes. Disfungsi endotelial, perubahan aliran darah tekanan darah dan permeabilitas pembuluh darah akibat hiperglikemi menjadi penyebab utama mikroangiopati (Perrin, 2007) 
sehingga merusak kemampuan endotel pembuluh darah untuk berelaksasi. Stress oksidatif berperan dalam patogenesis diabetes. Konsekuensi dari meningkatnya status oksidatif adalah: Kerusakan DNA, kerusakan lipid, reaksi anti oksidan dan degradasi protein (Calabrese dkk, 2007). Reactive oxygen species (ROS) dihasilkan selama aktifitas fisiologi (kondisi normal), ROS bereaksi dengan berbagai biomolekul seperti karbohidrat, lipid, protein, asam nukleat dan makromolekul dari jaringan ikat, sehingga mempengaruhi fungsi sel.

Pada kondisi normal sistem antioksidan tubuh bekerja untuk menyapu oksigen radikal tersebut. Pada kelainan metabolisme, terjadi ketidakseimbangan antara ROS yang dihasilkan dengan antioksidan yang ada maka terjadi hiperproduksi ROS, hal ini menyebabkan timbulnya stres oksidatif. Stres oksidatif adalah salah satu komponen pada mekanisme kerusakan jaringan pada manusia. Banyak dari komponen oksigen khususnya aldehid seperti malondialdehid (MDA) dihasilkan selama serangan radikal bebas pada membran lipoprotein(Yang, dkk, 2008). Salah satu akibat dari ROS adalah menebalnya membran glomerulus sebagai hasil dari glikosilasi dan meningkatnya tekanan intrarenal sehingga terjadi kerusakan ginjal kronik yang ditandai dengan meningkatnya kadar urea dan kreatinin serum, proteinuria dan menurunnya laju filtrasi glomerulus ginjal (Nobrega, dkk, 2004).

Realita yang ada menunjukkan bahwa masyarakat banyak yang menggunakan obat alternatif untuk mengatasi masalah tingginya biaya perawatan kesehatan. Obat diabetes yang biasanya digunakan selain mahal juga memiliki efek samping terhadap hati dan pencernaan (Murrai, dkk, 2002) sehingga perlu mencari alternatif dari alam yang memiliki kandungan seperti obat-obat anti diabetes diantaranya tanaman yang bersifat inhibitor $\alpha$-glukosidase dan yang mengandung senyawa asam fenolat seperti thiazolidinediones yang dapat meningkatkan sensitifitas insulin(9).

Kedelai (Glycine soja) adalah salah satu makanan fungsional yang memiliki keuntungan bagi tubuh(Jones, 2002) yang memiliki manfaat sebagai antikarsinogenik, antioksidan, antidiabetik dan antilipidemik (Kwon dkk, 2006). Sebagai antidiabetik kedelai memiliki beberapa manfaat, diantaranya adalah: mengurangi degradasi insulin, mengandung isoflavon yang berefek sebagai hipokolesterolemia (Borradaile dkk, 2002), meningkatkan sensifitas insulin (Kwon, dkk, 2006) karena mengandung komponen asam fenolat, memperbaiki sekresi insulin dan memiliki efek sebagai inhibitor $\alpha$-glukosidase yang menghalangi penyerapan glukosa di usus. Pemberian protein kedelai dapat meningkatkan reseptor insulin pada tikus wistar. Diet kedelai juga bisa mencegah kegemukan karena kegemukan adalah salah satu yang dapat meningkatkan resistensi insulin. Konsumsi protein kedelai bisa mengurangi resiko penyakit kardiovaskular dan penyakit ginjal pada pasien diabetes dengan nefropati. Di negara Asia, kedelai telah dikonsumsi sejak lama sebagai sumber protein (Kwon, dkk, 2006).

Kandungan serat pada kedelai dapat melindungi dari diabetes karena dapat mengurangi penyerapan glukosa di usus, memiliki indeks glikemik yang rendah. Protein kedelai dapat mengurangi jaringan lemak dengan cara menghambat pembentukan lemak dan meningkatkan penggunaan lemak di hati dan jaringan lemak. Penelitian terbaru menemukan bahwa isoflavon merupakan antidiabetik. Seratnya terdiri dari kompleks karbohidrat yang menimbulkan rasa kenyang sehingga dapat mengurangi asupan glukosa dari luar tubuh. Menurut Azadbakht (2008), 
mengkonsumsi protein kedelai dapat menurunkan kadar glukosa darah

Konsumsi protein kedelai memiliki pengaruh yang baik pada nefropati diabetes dengan cara mempengaruhi kadar lipid darah. Selain itu konsumsi protein kedelai dapat mengurangi kerusakan ginjal akibat diabetes dengan menurunkan proteinuria. Hipotesis Brenner menyatakan bahwa peningkatan masukan protein dapat menyebabkan hiperfiltrasi dan hipertensi glomeruus yang berdampak pada kerusakan fungsi ginjal yang menyebabkan nefropati pada diabetes. Peneliti menganjurkan untuk mengganti protein hewani dengan protein nabati yang berasal dari kedelai sehingga bisa melindungi dari kerusakan ginjal.

Kedelai memiliki beberapa kandungan fungsional yaitu, protein kedelai, isoflavon, saponin, asam fitat dan asam fenolat. Isoflavon dan saponin memiliki efek dalam mengurangi peroksidasi lemak, sehingga dapat mencegah terjadinya atherogenesis. Asam fenolat merupakan sejenis senyawa yang dapat meningkatkan sensitifitas insulin (Carruthers dkk., 2000). Isoflavon kedelai merupakan bagian penting dari kelas fitoestrogen, yang dalam penelitian terbukti: Menurunkan oksidasi in vivo, merangsang pembentukan NO (nitric oxide), memperbaiki compliance arterial sistemik dan mengatur keseimbangan garam dan air. Dengan demikian diperkirakan bahwa kedelai memberikan perlindungan terhadap terjadinya hipertensi. Konsumsi kedelai juga diperkirakan mengurangi konsentrasi CRP (C-reactive protein) yang merupakan penanda inflamasi sistemik yang berhubungan dengan kejadian hipertensi.

Isoflavon kedelai salah satu dari fitoestrogen yang terdiri dari tiga senyawa dalam empat bentuk sediaan kimia yaitu : aglycones (daidzein, genistein dan glycitein), glucosides (daidzin, genistin and glycitin), their malonyl-glycoside dan acetyl-glycoside. Penelitian terbaru melaporkan bahwa genistein dapat meningkatkan sekresi insulin pada pankreas tikus DM (Liu dkk., 2006) dan efektif mencegah terjadinya oksidasi LDL.

Penelitian-penelitian dalam skala kecil lainnya memperlihatkan bahwa konsumsi kedelai dapat menurunakan tekanan darah, walaupun hasilnya secara keseluruhan belum dapat dikatakan konsisten. Dalam suatu penelitian juga diketahui bahwa konsumsi protein kedelai dapat meningkatkan eNOS (endothelial nitric oxide synthase) dan ekspresi gen pada pembuluh darah dan jaringan lain, sehingga mengurangi stress oksidatif dan meningkatkan bioavailabilitas NO (nitric oxide), sehingga pemberian protein kedelai dapat merupakan terapi alternatif pada pasien wanita pasca-menopause dan pasien dengan risiko penyakit jantung koroner. Pada penelitian lainnya diketahui bahwa, pemberian susu kedelai dalam jangka waktu yang lama memiliki pengaruh hipotensi yang bermakna pada pasien hipertensi (Quan dkk., 2009)

Isoflavon menghambat aterosklerosis, antiproliferasi, antimigrasi dari sel-sel otot polos dan mempertahankan kenormalan pembuluh darah. Isoflavon pada kedelai merupakan antioksidan utama yang menekan peroksidasi lemak pada hati dan ginjal tikus diabetes.

Hiperglikemia menyebabkan terjadinya stres oksidatif dan meningkatnya reactive oxygen species (ROS) dan reactive nitrogen species (RNS). ROS termasuk radikal bebas seperti superoksida $\left(\mathrm{O}_{2}^{-}\right)$, hidroksil $(\mathrm{OH}), \quad$ peroksil $\left(\mathrm{RO}_{2}\right)$, hidroperoksil $\left(\mathrm{HRO}_{2}\right)$. RNS termasuk radikal bebas seperti nitrit oksid (NO) dan nitrogen dioksid $\left(\mathrm{NO}_{2}^{-}\right)$. Molekul reaktif $\mathrm{O}^{-}$ 2, NO dan $\mathrm{ONOO}^{-}$berperan penting dalam terjadinya komplikasi DM (Johansen, 2005). 


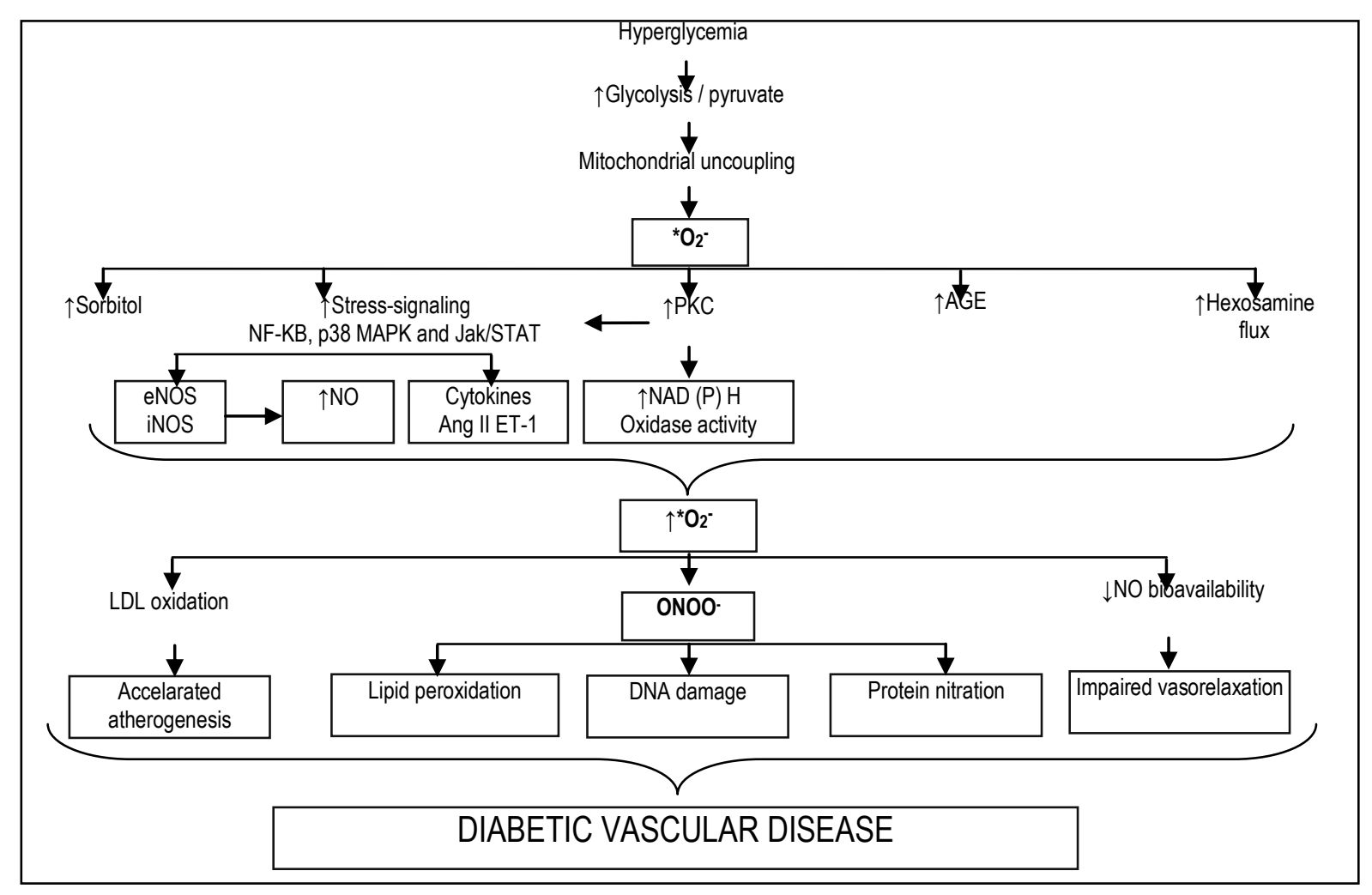

Gambar 1. Model Produksi ROS dan target kerusakannya pada DM (Johansen, dkk., 2005)

Dalam kondisi normal ROS merupakan molekul pensinyal dalam mekanisme pertahanan tubuh seperti pada proses fagositosis, fungsi netrofil, dan merangsang vasorelaksasi. Peningkatan ROS mengakibatkan efek patologis yaitu kerusakan protein, lipid dan DNA. ROS merangsang oksidasi LDL sehingga reseptor LDL tidak mengenalinya. LDL yang tidak dikenali akan difagosit oleh magrofag membentuk sel busa dan plak atherosklerosis. $\mathrm{O}_{2}^{-}$dapat mengaktifasi beberapa jalur kerusakan pada DM termasuk mempercepat pembentukan glycation end products (AGE), polyol pathway, hexosamine pathway and PKC, semua itu telah terbukti mengakibatkan komplikasi mikro dan makrovaskular.
Mekanisme yang terjadi dari komplikasi mikrovaskular dan makrovaskular pada DM tersebut adalah:

a. Reaksi kimia antara produk gula dengan protein yang terjadi lebih dari beberapa hari sampai beberapa minggu yang menghasilkan derivat protein yang irreversible yang disebut dengan AGE (Advanced glycation end products). Derivat ini menyebabkan terjadinya penebalan kolagen dan endotel, mempercepat aterosklerosis, disfungsi glomerulus, berkurangnya pembentukan nitrit oksid dan merubah komposisi serta struktur matriks ekstraselular (Braunwald dkk., 2008). AGE dapat merangsang penghambatan faktor pertumbuhan apoptosis sel-sel perisit retina, merangsang produksi yang 
berlebihan dari faktor pertumbuhan endotel, meningkatkan pembentukan pembuluh darah yang patologi dan meningkatkan inflamasi pembuluh darah. AGE dapat mengikat proteinprotein reseptor imunoglobulin untuk AGE dan menghasilkan peristiwa cascade kerusakan sel-sel endotel. AGE berperan penting pada penyakit nefropati DM yang menyebabkan apoptosis sel-sel mesangial dan merubah protein matriks ekstraselular sehingga menimbulkan hiperfiltrasi glomerulus dan sklerosis glomerulus. Pembentukan AGE juga merangsang sekresi yang berlebihan dari faktor anti pertumbuhan seperti insulin-like growth factor 1 dan transforming growth factor beta yang menyebabkan menurunnya area permukaan glomerulus untuk filtrasi.

b. Merangsang jalur PKC, protein kinase $c$ (sejenis molekul pensinyal dan ekspresi gen dari faktor pertumbuhan dan sinyal inflamasi yang meningkatkan permeabilitas vaskular). PKC dapat merangsang faktor pertumbuhan dan sitokin. PKC merupakan sumber dihasilkannya ROS pada DM yang akhirnya berkontribusi pada komplikasi mikrovaskular dan makrovaskular (Inoguchi, 2003)

c. Meningkatkan metabolisme glukosa melalui jalur sorbitol. Sejumlah glukosa dirubah menjadi sorbitol oleh enzim aldos reduktase. Peningkatan konsentrasi sorbitol merubah potensial redoks, meningkatnya osmolalitas selular, menghasilkan ROS dan memicu berbagai disfungsi selular (Cade, 2008).

d. Hiperglikemia meningkatkan jalur flux heksosamin yang menghasilkan fruktosa 6 fosfat, substrat untuk glikosilasi dan pembentukan proteoglikan. Jalur heksosamin merubah fungsi oleh glikosilasi protein seperti pembentukan nitrit oksid endotel atau dengan merubah ekspresi gen dari transforming growth factor beta (TGF beta) atau plasminogen activator inhibitor 1 (PAI-1)

Molekul $\mathrm{O}_{2}^{-}$dan $\mathrm{H}_{2} \mathrm{O}_{2}$ merangsang stress yang dihubungkan dengan mekanisme pensinyal seperti NF- $\mathrm{B}$, p38-MAPK and STAT-JAK menghasilkan proliferasi dan migrasi VSMC (vascular smooth muscular cell). Pada sel-sel endotel, $\mathrm{H}_{2} \mathrm{O}_{2}$ memperantarai apoptosis dan angiogenesis patologis. $\mathrm{O}_{2}^{-}$dengan segera bereaksi dengan NO menghasilkan sitotoksik $\mathrm{ONOO}^{-}$ dan reaksi ini mengakibatkan beberapa hal. pertama, $\mathrm{ONOO}^{-}$merubah fungsi dari biomolekul oleh nitrasi protein seperti yang terjadi pada lipid peroksidasi contohnya gerbang kalium yang mengatur respon vasorelaksasi yang dihambat oleh nitrasi. Hasil penelitian terbaru menjelaskan bahwa meningkatnya level nitrotirosin dihubungkan dengan apoptosis sel-sel miosit, sel-sel endotel dan fibroblas pada DM. Kedua, $\mathrm{ONOO}^{-}$menyebabkan singlestrand DNA lepas yang mengaktifasi perubahan nuclear enzyme poly (ADPribose) polymerase (PARP). Ketiga, ROS menurunkan bioavailabilitas NO menyebabkan berkurangnya relaksasi dan menghambat efek antiproliferasi NO. ROS merangsang peroksidasi membran lipid yang merubah struktur dan fluiditas membran yang menyebabkan patogenesis dari disfungsi vaskular.

Pada stres oksidatif terjadi ketidakseimbangan antara radikal bebas dengan antioksidan. Ada beberapa jenis antioksidan yang dapat menetralkan ROS. Antioksidan enzimatis yang dapat mengurangi ROS yaitu superoksida dismutase (SOD), katalase, dan glutasion peroksidase. SOD mengkatalis pembuangan radikal superoksida dengan cepat. Pada mamalia ada beberapa tipe SOD. Yang menjadi faktor pembedanya adalah lokasi mereka dalam sel dan ion metal yang mereka gunakan untuk fungsinya. Contoh SOD zinc yang berada dalam sitosol dan ruang antara dua membran mitokondria. 
SOD mangan yang berada dalam matriks mitokondria, kedua enzim ini penting untuk mencegah kerusakan dari ROS. Katalase dan glutasion peroksidase adalah enzim yang dapat membuang hidrogen peroksida. Salah satu cara katalase mengurangi hidrogen peroksida adalah dengan mengkatalis reaksi dua molekul hidrogen peroksida menjadi air dan oksigen. Glutasion peroksidase dapat berinteraksi secara langsung dengan ROS untuk menetralkan mereka. Antioksidan nonenzimatis yang berada di dalam sel adalah vitamin E ( $\alpha$-tocopherol $)$ and vitamin C (ascorbat). Vitamin E adalah antioksidan utama yang ditemukan pada lipid membran yang bertindak mengakhiri peroksidasi lipid.

Karakteristik dini dari nefropati diabetes adalah meningkatnya produksi urin (hiperfiltrasi), mikroalbuminuria (albumin urin 30-300 mg/hari), hipertropi glomerulus dan ginjal, akumulasi matriks mesangial dan penebalan membran basal glomerulus. Pada tahap akhir, apabila nefropati diabetes terus berlanjut pasien akan menderita proteinuria (albumin urin > $300 \mathrm{mg} / \mathrm{hari}$ ), menurunnya fungsi ginjal, menurunnya kreatinin klirens, glomerulosklerosis, fibrosis interstitial. Hiperglikemi menyebabkan timbulnya reaksi kimia antara produk gula dengan protein yang terjadi lebih dari beberapa hari sampai beberapa minggu yang menghasilkan derivat protein yang irreversible yang disebut dengan AGE (Advanced glycation end products). Derivat ini menyebabkan terjadinya penebalan kolagen dan endotel, mempercepat aterosklerosis, disfungsi glomerulus, berkurangnya pembentukan nitrit oksid dan merubah komposisi serta struktur matriks ekstraselular. Penurunan jumlah nefron fungsional akan menurunkan GFR dan menurunkan eksresi air dan zat terlarut oleh ginjal. Banyak produk buangan metabolisme seperti ureum dan kreatinin menumpuk hampir sebanding dengan nefron yang rusak. Selain itu kerusakan glomerulus juga menyebabkan hilangnya protein ke dalam urin (proteinuria). Hal ini terjadi karena peningkatan permeabilitas membran glomerulus. Hilangnya muatan negatif normal pada membran basal kapiler glomerulus memungkinkan protein, khususnya albumin, dengan mudah melewati membran glomerulus karena muatan negatif pada membran basal normalnya menolak muatan negatif protein plasma.

\section{KESIMPULAN DAN SARAN}

Protein kedelai memiliki efek yang menguntungkan dibandingkan dengan protein hewani. Hal ini disebabkan oleh isoflavon, asam amino yang dikandungnya, dapat menurunkan kadar lipid darah, efek antioksidan yang kuat untuk mencegah terjadinya oksidasi lipid dan dapat mengurangi terjadinya aterosklerosis dan memiliki efek antiinflamasi sehingga mencegah terjadinya gangguan pada ginjal.

\section{DAFTAR PUSTAKA}

Rebsomen, L., Khammar, A., Raccah,D. and Tsimaratos, M. 2008. CPeptide Effects on Renal Physiology and Diabetes. Ex Diabetes Research. 281536.

Auroma, O. I. 2006. Free radicals, Antioxidants and Diabetes: Embryopathy, Retinopathy, Neuropathy, Nephropathy and Cardiovascular Complications Neuroembryol Aging. 4: 117-137.

O'Brien, J. A., Patrick, A. R. and Caro, J.J. 2003. Cost of Managing Complications Resulting from Type 2 Diabetes Mellitus in Canada. Biomedical Centre Health Services Research. 3: 7.

Perrin, R. M., Harper, S. J. and Bateset, D. O. 2007. A Role for the Endothelial 
Glycocalyx in Regulating Microvascular Permeability in Diabetes Mellitus. Cell Biochemistry Biophys. 49 (2): 6572.

Calabrese, V., Mancuso, C., Sapienza, M., Puleo, E.,Calafato, S., Cornelius, C., Finocchiaro, M., Mangiameli, A., Di Mauro, M., Stella, A.M.G. and Castellino, P. 2007. Oxidative Stress And Cellular Stress Response in Diabetic Nephropathy. Cell Stress Chaperones. 12 (4): 299-306.

Yang, R., Shi, Y.H., Hao, G., Li, W. and Le, G.W. 2008. Increasing Oxidative Stress with Progressive Hyperlipidemia in Human: Relation between Malondialdehyde and Atherogenic Index. Journal Clinical Biochemistry Nutrition. 43 (3): 154-158.

Nobrega, M. A., Fleming, S., Roman, R. J., Shiozawa, M., Schlick, N., Lazar, J. and Jacob, H.J. 2004. Initial Characterization of a Rat Model of Diabetic Oxidation and Energy Expenditure in Type II Diabetic Mice. Diabetes. 53: 735-742

Murai. A., Iwamur. K., Takada. M., Ogawa. K., Usui, T. and Okumura, J. 2002. Control of postprandial hyperglycaemia by galactosyl maltobionolactone and its novel antiamylas effect in mice. Life Science. Vol.71: 1405-1415.

Carruthers, S. G., Hoffman, B. B., Melmon, K. L. and Nierenberg, D. W. 2000. Melmon and Morrelli's Clinical Pharmacology. Mcgraw Hill Company.

Jones, P. J. 2002. Clinical Nutrition: 7. Functional Foods More than just Nutrition. Canadian Medical Association Journal. Vol.12: 15551563.
Kwon, D. Y., Jang, J. S., Hong, S. M., Lee, J. E., Sung, S. R. and Park, H. R. 2006. Long-Term Consumption Of Fermented Soybean-Derived Chungkookjang Enhances Insulinotropic Action Unlike Soybeans In 90\% Pancreatectomized Diabetic Rats. Europe Journal Nutrition. 46: 44-52.

Borradaile, N. M., De Dreu, L. E., Wilcox, L. J., Edwards, J. Y. and Huff, M. W. 2002. Soya phytoestrogens, genistein and daidzein, decrease apolipoprotein B secretion from HepG2 cells through multiple mechanisms. Biochemical Journal. 366: 531-539 